
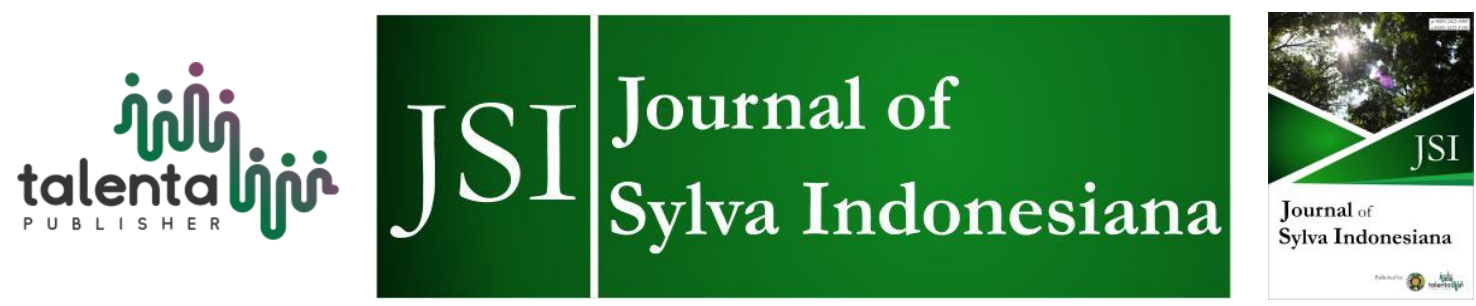

\title{
Analysis of Above Ground Carbon as Indicator for Forest Health in Protection Forest Registers 25
}

\author{
Rayi Nindya Lestari', Christine Wulandari ${ }^{2}$, Rahmat Safe'i $^{3}$, Arief \\ Darmawan $^{4}$ \\ 1,2,3,4 Forestry Department, Faculty of Agriculture, Lampung University, Bandar Lampung, Indonesia
}

\begin{abstract}
Forest health is very important in world global change issues. The problem such as air pollution, acid rain, forest fires, quality and quantity of water, and global climate change has affected the realization of a sustainable forest. Achievement of forest preservation in forest ecosystem, criteria and indicators had been widely formulated. Therefore, carbon analysis is significantly needed to figure the indicator of forest health. The aim of the research was to analyze the carbon as a forest health indicator in Protection Forest, Reg. 25. The data were collected through cluster plot based on Forest Health Monitoring (FHM) method. The formula for counting biomass within the tree was $\mathrm{W}=$ $0,11 \times \rho \times \mathrm{D} 2,62$, mean while under growth and litter biomass are gained from total dry weight. Carbon sink is based on conversion number; 0,5 out of total biomass number. The average of carbon stored in Protection Forest Reg. 25 is about 939,12 ton/ha. Carbon within the stands are contributed the most; 937, 43 ton/ha, litter carbon about 1,06 ton C/ha and undergrowth carbon is about 0,63 ton $\mathrm{C} / \mathrm{ha}$. Based on the analysis, carbon can be a health indicator of Protection Forest Register 25 with the category of poor, moderate, and good. Cluster plots 1 and 2 classified to good category (1,232.75 ton C/ha - 1744.13 ton C/ha), while cluster plots 3 and 4 classified to poor category (209.97 ton C/ha - 721.35 ton C/ha).
\end{abstract}

Keyword: Carbon, cluster plot, forest health indicator, protection forest register 25

Received 29 October 2017 | Revised 24 December 2018 | Accepted 29 March 2019

\section{Introduction}

Recently, global climate changes become phenomenon issue. One of global climate changes issu forest degradation. According to [1]-[2], forest degradation causing carbon dioxide $\left(\mathrm{CO}_{2}\right)$ emissions, whereas forests have ability to absorb $\mathrm{CO}_{2}$ or known as carbon sinks.

According to [3], the forestry sector has great potential in absorbing carbon through planting, increasing forest growth, reducing the rate of deforestation and forest fires. These functions

\footnotetext{
*Corresponding author at: Lampung University, Jl. Prof. Dr. Soemantri Brojonegoro No. 1 Gedung Meneng Bandar Lampung 35145

E-mail address: lestari.rayi@gmail.com
} 
show that the forest is one of main elements as a regulator of earth's climate locally, regionally and globally.

The achievement of forest ecosystem sustainability criteria, and indicators have been formulated or developed by government and non-governmental institutions in national, regional and international levels [4]. The health of forest ecosystems becomes very important throughout the world when various global issues such as air pollution, acid rain, forest fires, problems with quality and quantity of water, and global climate change have affected the realization of sustainable forests. Criteria are usually expressed as conditions or situations in the aspect of the forest whose process must be carried out, while indicators are usually expressed as something special that can be assessed in relation to the criteria [5].

The measured health indicators of forest ecosystems differed depending on achieved forest management efforts. In this study, carbon was used as a health indicator for Protection Forest Register 25. The purpose of this study is to observe carbon as forest health indicator for Protected Forests in Register 25. There is no carbon data from the Protected Forests Register 25. Therefore, a carbon analysis in this area needs to be carried out.

According to [6], the knowledge about stored carbon allows to know the area function in supporting greenhouse gas emission reduction which is one of factor the causes of global climate change. Healthy forests actively store carbon through forest growth, resist of the pathogen and the outbreak of insect and recovery from damages such as forest fire [7].

\section{Materials and Methode}

The study was conducted in Protection Forest Register 25, Kelumbayan District, Tanggamus Regency. The data obtained by using plot clusters based on the Forest Health Monitoring (FHM) method according to [8]-[9]. Each plot cluster (Figure 1.) consists of four plots. The location of plot cluster was determined based on purposive sampling. Four plot clusters consist of two plot clusters in the primary forest area and two plot clusters in the secondary forest area.

The important value index (INP) and tree biomass parameter those were tree species, tree diameter, and tree height were measured. Based on [10], the sampling of litter and understorey biomass was determined as follows: if the wet weight is more than 300 grams, then the used sample is 300 grams. If the wet weight obtained is less than 300 grams, then the sample used is 100 grams. If the wet weight obtained is less than 100 grams, the used sample is as much as that obtained. 


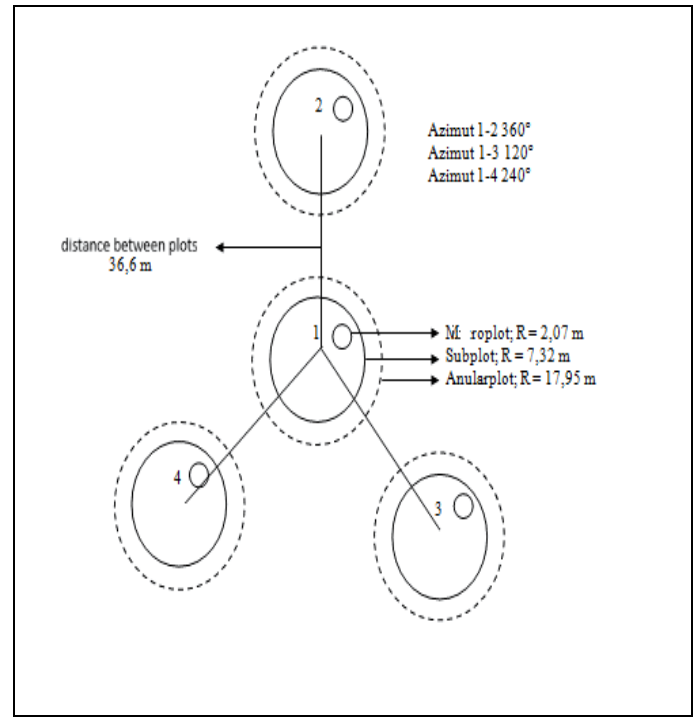

Figure 1 Cluster plot design

Source: [9]-[10]

Description: Annular plots for retrieval of tree biomass and Important Value Index (INP) data. Micro-plot for the collection of understorey and litter biomass data.

The Important Value Index (IVI) on vegetation can be calculated based on the Ministry of Environment Decree No. 201 year 2004 with the following equation:

$$
\begin{aligned}
& \mathrm{K}=\frac{\text { Individual number of a species }}{\text { Area of all sample plots }} \\
& \mathrm{KR}=\frac{\text { Density of a species }}{\text { Density of all species }} \times 100 \% \\
& \mathrm{~F}=\frac{\text { Number of plots a species found }}{\text { Number of all plots }} \\
& \mathrm{FR}=\frac{\text { Frequency of a species }}{\text { Frequency of all species }} \times 100 \% \\
& \mathrm{D}=\frac{\text { Basal area of a species }}{\text { Area of all sample plots }} \\
& \mathrm{DR}=\frac{\text { Dominancy of a species }}{\text { Dominancy of all species }} \times 100 \%
\end{aligned}
$$

Based on the equation, the formula to calculate the species' IVI is:

$$
\mathrm{IVI}=\mathrm{RD}+\mathrm{RF}+\mathrm{RD}
$$

Description: $\mathrm{D}=$ Density, $\mathrm{RD}=$ Relative Density, $\mathrm{F}=$ Frequency, $\mathrm{RF}=$ Relative Frequency, $\mathrm{D}=$ Dominancy, RD = Relative Dominancy

The measurement of biomass in trees done by measuring the diameter at breast height and tree height then was analyzed using the general allometric equation proposed by [1], which is

$$
\mathrm{W}=0,11 \times \rho \times \mathrm{D}^{2,62}
$$


Description:

$\mathrm{W}=$ biomass $(\mathrm{kg})$

$\rho \quad=$ wood density $\left(\mathrm{g} / \mathrm{cm}^{3}\right)$

$\mathrm{D}=$ diameter at breast height $(\mathrm{cm})$

The obtained total tree biomass $(\mathrm{kg})=\mathrm{DW} 1+\mathrm{DW} 2+\ldots \ldots \ldots .+\mathrm{DWn}$

Description:

DW $\quad=$ Dry Weight

The formula for calculating biomass per unit area (tons/ha) as follows:

$$
\text { Total Biomass }(\mathrm{kg}) / \text { Area }\left(\mathrm{m}^{2}\right)
$$

The measurements of litter and understorey biomass were carried out by weighing wet weight data then oven at a temperature of $800^{\circ} \mathrm{C}$ until the weight was constant. The sample was then weighed as dry weight. Both samples can be used to estimate biomass using the Biomass Expansion Factor formula [11].

$$
\text { Total DW }=\frac{\text { DW of sub sample }\left(g \mathrm{gr}^{2}\right)}{\text { WW of sub sample } \left.(\mathrm{gr})^{2}\right)} \times \text { total WW }
$$

Description:

DW $=$ Dry Weight $($ gr $)$

$\mathrm{WW}=$ Wet Weight (gr)

After the biomass value was obtained, carbon calculation was carried out. According to [12], the carbon fraction from biomass is 0.50 (0.44 to 0.55$)$, which means that $50 \%$ of the biomass is stored carbon, so a large amount of stored carbon can be calculated.

There are 3 health categories on Protected Forest Register 25, namely poor, medium, and good. These categories were obtained by calculating the threshold value of the carbon volume above the ground. The carbon volume threshold value above the ground was obtained based on the highest and lowest values of carbon volume calculation on each plot cluster.

\section{Results and Discussion}

\subsection{Important Value Index in Protection Forest, Register 25}

Important Value Index (IVI) is calculated to determine the importance of a plant species and its role in the community and the important values on tree and seedling levels of vegetation. The greater Important Value Index of species, greater of community dominance level and vice versa 
[13]. In order to discover the relation between tree phase IVI and the amount carbon measured, the IVI calculation in the Protected Forest Register 25 was conducted only on tree phase.

Table 1 Results of tree stage Important Value Index calculations in Protection Forest Register 25

\begin{tabular}{|c|c|c|c|c|c|c|}
\hline \multirow[b]{2}{*}{ No } & \multicolumn{2}{|c|}{ Tree species } & \multicolumn{4}{|c|}{ Register 25} \\
\hline & $\begin{array}{l}\text { Local } \\
\text { name }\end{array}$ & Scientific name & $\begin{array}{c}\text { Plot } \\
\text { cluster } 1 \\
(\%)\end{array}$ & $\begin{array}{c}\text { Plot } \\
\text { cluster } 2 \\
(\%)\end{array}$ & $\begin{array}{c}\text { Plot } \\
\text { cluster } 3 \\
(\%)\end{array}$ & $\begin{array}{c}\text { Plot } \\
\text { cluster } 4 \\
(\%)\end{array}$ \\
\hline 1 & Waru & Hibiscus tiliaceus & 41.97 & 72.75 & - & - \\
\hline 2 & Dadap & Erythrina variegata & 19.11 & 7.07 & - & - \\
\hline 3 & Medang & Litsea sp. & 45.36 & 35.5 & - & - \\
\hline 4 & Cempaka & Michelia alba & 35.70 & - & - & - \\
\hline 5 & Suren & Toona sureni & 17.56 & 16.92 & - & - \\
\hline 6 & Mangir & $\begin{array}{l}\text { Ganophyllum } \\
\text { falcatum }\end{array}$ & 9.66 & - & - & - \\
\hline 7 & Bayur & $\begin{array}{l}\text { Pterospermum } \\
\text { javanicum }\end{array}$ & 46.27 & 52.23 & - & - \\
\hline 8 & Beringin & Ficus benjamina & 18.54 & 12.72 & - & - \\
\hline 9 & Meranti & Shorea sp. & 24.53 & 29.77 & - & - \\
\hline 10 & Gondang & Ficus variegata & 25.16 & 7.07 & - & - \\
\hline 11 & Jaha & Terminalia bellirica & 9.93 & - & - & - \\
\hline 12 & Sonokeling & Dalbergia latifolia & 6.22 & 18.22 & - & - \\
\hline 13 & Durian & Durio zibethinus & - & - & 127.85 & 120.67 \\
\hline 14 & Mangga & Mangifera indica & - & - & 26.74 & - \\
\hline 15 & Melinjo & Gnetum gnemon & - & - & 75.05 & 45.78 \\
\hline 16 & Cengkeh & Syzygium aromaticum & - & - & 39.90 & 45.88 \\
\hline 17 & Jambu air & Syzygium aquеuт & - & - & 14.92 & - \\
\hline 18 & Petai & Parkia speciosa & - & - & 15.54 & 87.67 \\
\hline Total & & & 300 & 300 & 300 & 300 \\
\hline
\end{tabular}

Bayur (Pterospermum javanicum) obtained the highest IVI on plot cluster 1 that is $46.27 \%$. On plot cluster 2, the highest IVI obtained by waru (Hibiscus tiliaceus) with a value of $72.75 \%$. On plot cluster 3 and 4, the highest IVI obtained by durian (Durio zibethinus) with a value of $127.85 \%$ and $120.67 \%$, respectively (Tabel 1). The highest IVI of all was obtained by durian (Durio zibethinus) on plot cluster $3(127.85 \%)$, and the lowest obtained by sonokeling (Dalbergia latifolia) on plot cluster $1(6.22 \%)$.

\subsection{Measurement Results of Stored Carbon in Protected Forest, Register 25}

The above ground biomass and carbon measurements in Protected Forest Register 25 were carried out in 4 plot clusters. Plot clusters 1 and 2 were located in the primary forest, while plot clusters 3 and 4 were located in the secondary forest. 


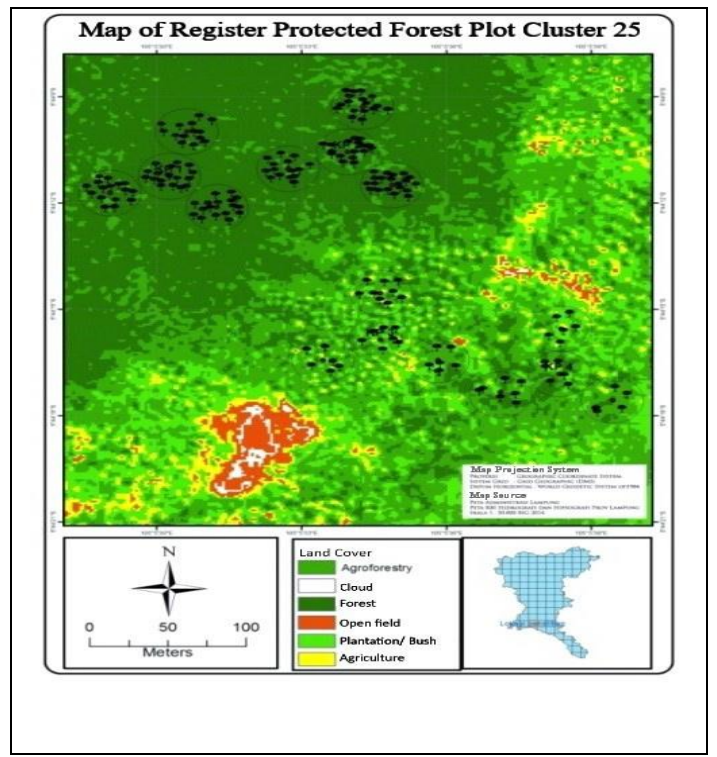

Figure 2 Carbon analysis plot clusters distribution map on Protected Forest, Register 25

Plot cluster 1 located in the primary forest of Protected Forest Register 25 and stored biomass of $3,484.49$ tons/ha or carbon of $1,742.25$ tons/ha. The largest due to its considerable amount of trees and diameters compared to other plot clusters. The number of trees in plot cluster 1 was 68 trees consisted of 12 tree species, namely waru (Hibiscus tiliaceus), dadap (Erythrina variegata), medang (Litsea sp.), cempaka (Michelia alba), suren (Toona sureni), mangir (Ganophyllum falcatum), bayur (Pterospermum javanicum), beringin (Ficus benjamina), meranti (Shorea sp.), gondang (Ficus variegata), jaha (Terminalia bellirica) and sonokeling (Dalbergia latifolia).

Plot cluster 2 contributed 3,176.44 tons/ha or 1,588.22 tons C/ha to the stand biomass carbon of Protected Forest Register 25. The number of trees in plot 2 cluster was 64 trees with 9 species of trees namely waru (Hibiscus tiliaceus), dadap (Erythrina variegata), medang (Litsea sp.), suren (Toona sureni), bayur (Pterospermum javanicum), beringin (Ficus benjamina), meranti (Shorea sp.), gondang (Ficus variegata) and sonokeling (Dalbergia latifolia).

Plot cluster 3 was located in the secondary forest with a contribution of the biomass of 422.14 tons/ha or carbon of 211.07 tons /ha. There were 29 individual trees of 9 species, namely durian (Durio zibethinus), mangga (Mangifera indica), melinjo (Gnetum gnemon), jambu air (Syzygyum aqueum), cengkeh (Syzygium aromaticum) and petai (Parkia speciosa).

Plot cluster 4 had the smallest stand carbon value compared to the other plot clusters due to its minor number and average tree diameter compared to other plot clusters. It contributed 416.35 tons/ha or carbon was 208.18 tons/ha of biomass. There were 24 trees in plot cluster 4 , consisted of 4 species, namely durian (Durio zibethinus), petai (Parkia speciosa), melinjo (Gnetum gnemon), and cengkeh (Syzygyum aromaticum). 
The carbon amount of litter and understorey in plot cluster 1 were 1.19 tons/ha and 0.66 tons/ha, respectively. Plot cluster 2 stored litter carbon by 0.81 tons/ha and understorey carbon by 0.61 tons/ha. The litter carbon of plot cluster 3 was 1.15 tons/ha while its understorey carbon was 0.55 tons/ha. Plot cluster 4-stored litter and understorey carbon with values of 1.08 tons/ha and 0.71 tons/ha, respectively.

\subsection{The Analysis of Stored Carbon on Protected Forest, Register 25}

The largest proportion of carbon storage on land is found in tree components or stands [10]. The four plot clusters were used for biomass measurements and to determine the values of carbon stored in the stands of Protected Forest Register 25. The values are presented in Table 2.

Table 2 The amount of biomass and carbon stored in the stands of Protected Forest Register 25

\begin{tabular}{llcc}
\hline No & Location & Biomass (ton/ha) & Stored Carbon (ton/ha) \\
\hline 1 & Plot cluster 1 & $3,484.49$ & $1,742.25$ \\
2 & Plot cluster 2 & $3,176.44$ & $1,588.22$ \\
3 & Plot cluster 3 & 422.14 & 211.07 \\
4 & Plot cluster 4 & 416.35 & 208.18 \\
\hline \multicolumn{2}{l}{ Total } & $7,499.42$ & $3,749.72$ \\
\hline Average & $1,874.86$ & 937.43 \\
\hline
\end{tabular}

Table 2 shows that the plot cluster 1 stored the largest biomass and carbon (46.46\%) with a biomass value of $3,484.49$ tons/ha or $1,742.25$ tons $\mathrm{C} /$ ha due to its largest average diameter compared to other cluster plots. In accordance with [14], the greater the diameter of a tree, the greater the biomass contained due to its ability to absorb more $\mathrm{CO} 2$. Plants absorb $\mathrm{CO} 2$ from the air and convert it into organic compounds through photosynthesis.

The stored biomass and carbon in litter and understorey in Protected Forest Register 25 were measured by taking samples on micro-plots in each cluster plot. Litter is defined as dead organic matter that is on the forest floor [15]. The results of measurements of stored biomass and carbon in litter and understorey in Protected Forest Register 25 are presented in Table 3.

Table 3 The amount of biomass and carbon stored in the litter and understorey of Protected Forest Register 25

\begin{tabular}{lccccc}
\hline \multirow{2}{*}{ No $\quad$ Location } & \multicolumn{2}{c}{ Litter } & \multicolumn{2}{c}{ Understorey } \\
\cline { 2 - 6 } & $\begin{array}{c}\text { Biomass } \\
\text { (ton/ha) }\end{array}$ & $\begin{array}{c}\text { Stored Carbon } \\
\text { (ton/ha) }\end{array}$ & $\begin{array}{c}\text { Biomass } \\
\text { (ton/ha) }\end{array}$ & $\begin{array}{c}\text { Stored Carbon } \\
\text { (ton/ha) }\end{array}$ \\
\hline 1 & Plot cluster 1 & 2.38 & 1.19 & 1.31 & 0.66 \\
2 & Plot cluster 2 & 1.61 & 0.81 & 1.21 & 0.61 \\
3 & Plot cluster 3 & 2.30 & 1.15 & 1.10 & 0.55 \\
4 & Plot cluster 4 & 2.16 & 1.08 & 1.41 & 0.71 \\
\hline \multicolumn{2}{l}{ Total } & 8.45 & 4.23 & 5.03 & 2.53 \\
\hline \multicolumn{2}{l}{ Average } & 2.11 & 1.06 & 1.26 & 0.63 \\
\hline
\end{tabular}


Litter and understorey biomass and carbon are influenced by the vegetation conditions where they grow. This is also stated by [16], that the biomass and carbon content of understorey is influenced by the composition of understorey vegetation. Similarly, the content of biomass and carbon in the litter is influenced by its constituent components, for example, rotten wood, leaves, and twigs.

The results of measurements of stored carbon from each cluster plot in Protected Forest Registered 25 are in Table 4.

Table 4 Stored carbon on each plot cluster of Protected Forest Register 25

\begin{tabular}{lcccccc}
\hline No & Location & $\begin{array}{c}\text { C stands } \\
\text { (ton/ha) }\end{array}$ & $\begin{array}{c}\text { C Litter } \\
\text { (ton/ha) }\end{array}$ & $\begin{array}{c}\text { C } \\
\text { Understorey } \\
\text { (ton/ha) }\end{array}$ & $\begin{array}{c}\text { Total } \\
\text { C/Cluster } \\
\text { (ton/ha) }\end{array}$ & $\begin{array}{c}\text { Persentage } \\
(\%)\end{array}$ \\
\hline 1 & Plot cluster 1 & $1,742.25$ & 1.19 & 0.66 & $1,744.10$ & 46.43 \\
2 & Plot cluster 2 & $1,588.22$ & 0.81 & 0.61 & $1,589.64$ & 42.32 \\
3 & Plot cluster 3 & 211.07 & 1.15 & 0.55 & 212.77 & 5.66 \\
4 & Plot cluster 4 & 208.18 & 1.08 & 0.71 & 209.97 & 5.59 \\
\hline \multicolumn{2}{l}{ Total } & $3,749.72$ & 4.23 & 2.53 & $3,756.48$ & \multirow{2}{*}{ Average } \\
\hline
\end{tabular}

Table 4 shows that plot cluster 1 contributed the largest stored carbon in the Protection Forest Register 25 that is $46.43 \%$ or $1,744.10$ tons $\mathrm{C} / \mathrm{ha}$. Cluster 1 also has the largest number and type of trees compared to other plot clusters according to the IVI calculations that have been carried out. It showed the correlation between the IVI value and carbon in vegetation. Greater IVI value will increase carbon stored. According to [17] stated that there is a significant positive relationship between IVI and biomass or carbon, which means an increase in IVI is proportional to biomass or carbon. The diameter of trees used to calculate biomass or carbon and dominance in IVI also affected this, so that the amount of biomass or carbon indirectly correlates with the dominance of the tree species.

Compared with the similar studies, the storage of above ground carbon in Protected Forest Register 25 was greater than that of Setanjo Protection Forest at Riau. According to [18], Setanjo Protection Forest stores 223.18 tons/ha carbon. The agroforestry area of Register 39 Datar Setuju at the Protected Forest Management Area Batutegi stored 178.24 tons/ha carbon. In conclusion, Register 25 was more carbon saving than the other regions.

The better ability of the Protection Forest Register 25 to store carbon showed that it has good ecological functions. According to [19], if a land cover has a good ecological function, it has a better ability to absorb or sink carbon.

\subsection{The Determination of Protected Forest Register 25's Health Category}

The carbon volume threshold value was used to determine the health category of Protection Forest Register 25. Based on the highest and the lowest values from the calculation of the 
above-ground carbon volume that has been carried out in all cluster plots, the health threshold value of Protection Forest Register 25 as follows:

Table 5 The health threshold value of Protected Forest Register 25

\begin{tabular}{cc}
\hline Threshold Value & $\begin{array}{c}\text { Health Category of Protected Forest } \\
\text { Register 25 }\end{array}$ \\
\hline 209.97 to 721.35 & Poor \\
721.36 to $1,232.74$ & Medium \\
$1,232.75$ to $1,744.13$ & Good \\
\hline
\end{tabular}

Based on the threshold values in Table 5, plot cluster 1 and 2 which stores 1,744.10 tons/ha and 1,589.64 tons/ha carbon, respectively, are included in the good category. Both clusters store the largest carbon compared to plot clusters 3 and 4. Due to their location on the primary forests which dominated by forestry plants, plot cluster 1 and 2 have the largest carbon deposit on their tree stands.

Plot cluster 3 and 4 stores 212.77 tons/ha and 209.97 tons/ha carbon, respectively, and classified into the poor category because their ability to store carbon was less than plot cluster 1 and 2 . Both cluster 3 and 4 plots were located in the secondary forests dominated by Multi-Purpose Tree species (MPTs) and plantation crops so that the carbon stored in the two cluster plots was smaller than the plot clusters dominated by forestry plants.

\section{Conclusion}

Based on the analysis, the above ground carbon can be used as a health indicator for Protection Forest Register 25 in classified into poor, medium and good. Plot cluster 1 and 2 categorized as good (1,232.75 tons C/ha to $1,744.13$ tons $\mathrm{C} / \mathrm{ha})$. Plot cluster 3 and 4 categorized as poor (209.97 tons C/ha to 721.35 tons C/ha).

\section{REFERENCES}

[1] Q.M. Ketterings, R. Coe, M. Van Noordjwik, Y. Ambagau, C.A. Palm, "Reducing uncertainty in the use of allometric biomass equations for predicting above ground tree biomass in mixed secondary forest," Journal Forest Ecology and Management, vol. 146, no. 2, pp. 199-209. 2001.

[2] A. Junaedi, "Forest contribution as carbon dioxide sink." Jurnal Info Hutan, vol. 5, no. 1, pp. 1-7. 2008.

[3] H. Setiawan, "Potential of KHDTK Malili as carbon dioxide sink in order to mitigate climate change," Jurnal Eboni, vol. 12, no. 1, pp. 1-12. 2015.

[4] R. Safe'i, "Health Study of Forests in Community Forest Management in Lampung Province," Disertation, IPB Bogor, p. 124. 2015.

[5] B. Ritchie, M.D. Cynthia, H. Mandy, B.O. Nicolette, Criteria and Indicators for the Sustainability of Forests Managed by Communities, Center for International Forestry Research, Jakarta, p.121, 2001.

[6] B.H. Suharjo, dan H.F.P. Wardhana, "Estimation of The Potential For Carbon Deposits in Pine Stands (Pinus Merkusii) at Cianjur KPH Perum Perhutani Unit III West Java and Banten," Journal of Tropical Silviculture, 03, pp. 96-100. 2011.

[7] EPA (Environmental Protection Agency), Inventory of U.S. Greenhouse Gas Emissions and Sinks: 1990-2012, Washington DC, p. 529. 2013. 
[8] R. Mangold, Forest Health Monitoring: Field Methods Guide, USDA Forest, USDA Forest Service General Technical Report, New York, p. 2461997.

[9] USDA (United States Department of Agriculture), Forest inventory and analysis national core field guide, Vol. 1: Field data collection procedures for phase 2 plots. 2005.

[10] K. Hairiah, R. Subekti, Carbon Measurements Stored in Various Land Uses, World Agroforestry Center-ICRAF, Bogor, p. 77. 2007.

[11] S. Brown, "Estimating Biomass and Biomass Change of Tropical Forest," a primer. FAO Forestry Paper 134, FAO Rome, 1997.

[12] IPCC (Intergovernmental Panel on Climate Change), In: Eggleston H.S., Buendia L., Miwa K., Ngara T. And Tanabe K. (Eds.), Intergovernmental Panel on Climate Change Guidelines for National Greenhouse Gas Inventories, Prepared by the National Greenhouse Gas Inventories Programme, IGES, Japan, 2006.

[13] A. Soegianto, Quantitative Ecology: Population and Community Analysis Methods, Usaha Nasional, Surabaya, p. 173. 1994.

[14] N.A. Campbell, J.B. Reece, L.G. Mitchell, Biology, Erlangga, Jakarta, p. 1247. 2002.

[15] D. Sutaryo, Calculation of Biomass: An Introduction to the Study of Carbon and Carbon Trading, Wetlands International Programme, Bogor, p. 482009.

[16] Asril, "Estimation of Carbon Reserves in the Surface of Peat Swamp Land at the Suaq Balimbing Research Station in South Aceh Regency, Nanggroe Aceh Darussalam Province," Thesis, North Sumatera University, Medan, Indonesia, p. 89. 2009.

[17] N.I. Wahyuni, "Correlation of Important Value Indexes for Tree Biomass in Bogani Nani Wartabone National Park Region, North Sulawesi," In Proceedings Manado Forestry Research Center, Manado, pp. 113-124. 2014.

[18] Pebriandi, E. Sribudiani, and Mukhamadun. "Estimation of The Potential for Carbon Above The Ground at The Pole and Tree Level in The Setanjo Protection Forest," Student's Online Journal, vol. 1, no. 1, pp. 1-13. 2013.

[19] A. Rachdian, "Identification of Changes in Environmental Services Using Remote Sensing and Geographic Information Systems in Bogor," Essay, IPB Bogor, p. 49. 2015. 